K A N D A I

\begin{tabular}{|l|l|l|}
\hline Volume 17 & No. 1, Mei 2021 & Halaman 105-118 \\
\hline
\end{tabular}

\title{
PERJUANGAN PEREMPUAN MENCAPAI EKSISTENSI DIRI DALAM NOVEL SINTREN \\ (Women's Struggle in Achieving Self-Existence in the Novel Sintren)
}

\author{
Ery Agus Kurnianto \\ Balai Bahasa Jawa Tengah \\ Jalan Elang Raya No. 1, Mangunhardjo, Semarang, Jawa Tengah, Indonesia \\ Pos-el: eryagus75@gamil.com
}

(Diterima: 18 April 2020; Direvisi: 27 Desember 2020; Disetujui: 19 Maret 2021)

\begin{abstract}
A cultural construction established by men has hindered women to be themselves. Women do not get equal opportunity as men to perform their abilities and to come into their existences. A novel, Sintren written by Dianing Widya Yudhistira, represents struggles performed by a female character to come into her existence. The problem in this research covers some problems faced by women to come into their self-existences and struggles performed by women characters in the novel amidst grounding efforts of myths about women. Descriptive method is applied in this study to analyze the problems of this research. The existentialist feminist theory is applied as a basis for answering the problems. The findings of the research show that the problems faced by women to come into their self-existences cover a strong determinant of patriarchal tradition in community life, poverty, and the ambivalent personality possessed by the women. To improve the quality of higher education, tp struggle to be themselves or self-liberation, and to earn capital are some strategies set by female characters in the novel to come into their existences.
\end{abstract}

Keywords: struggles, woman, self-existence, femininity

\begin{abstract}
Abstrak
Konstruksi budaya yang dibentuk oleh kaum laki-laki membuat perempuan tidak pernah menjadi dirinya sendiri. Perempuan tidak mendapatkan kesempatan untuk menunjukan kemampuan dan eksistensi dirinya. Novel Sintren merepresentasikan perjuangan tokoh perempuan untuk meraih eksistensinya. Masalah dalam penelitian ini ialah problematikayang dihadapi oleh kaum perempuan untuk mencapai eksistensi diri dan perjuangan kaum perempuan dalam novel Sintren karya Dianing Widya Yudhistira terhadap pembumian mitos tentang perempuan. Metode deskriptif digunakan untuk menganalisis persoalan yang dibahas. Teori feminisime eksistensialisme digunakan sebagai dasar untuk menjawab persoalan. Hasil temuan menunjukkan bahwa problematika yang dihadapi oleh kaum perempuan dalam mencapai eksistensi diri adalah tradisi patriarki yang sangat kuat dalam kehidupan masyarakat, kemiskinan, dan sifat ambivalen yang muncul dari diri perempuan itu sendiri. Pendidikan, menjadi diri sendiri atau pembebasan diri, dan menghasilkan modal capital menjadi startegi yang digunakan oleh tokoh perempuan agar dapa tmenunjukkan eksistensi dirinya.
\end{abstract}

Kat-kataa kunci: perjuangan, perempuan, eksistensidiri, feminis

DOI: $10.26499 / j k . v 17 i 1.2375$

How to cite: Kurnianto, E. A. (2021). Perjuangan perempuan mencapai eksistensi diri dalam novel Sintren. Kandai, 17(1), 105-118 (DOI: 10.26499/jk.v17i1.2375) 


\section{PENDAHULUAN}

Novel Sintren menarik diteliti dengan menggunakan teori feminis karena semangat perempuan untuk menunjukkan eksistensi diri terasa sangat kuat. Sejak kecil tokoh Saraswati diidentifikasi sebagai sosok perempuan yang berbeda dengan perempuanperempuan lain yang ada di desanya. Keinginan kuatnya untuk melanjutkan sekolah ke jenjang yang lebih tinggi digambarkan harus menghadapi tantangan-tantangan dan kendala yang sangat berat sebagai sosok perempuan yang "berbeda" dalam mendobrak dominasi dan mitos tentang sosok perempuan. Selain itu semangat feminis sangat kuat terepresentasi melalui tokoh Saraswati yang selalu dideskripsikan sebagai sosok yang melakukan perlawanan terhadap tradisi dan kemapanan konstruksi yang ada di lingkungan sosialnya. Karya sastra, apa pun genrenya, merupakan cerminan kehidupan sosial yang menunjukkan adanya sebuah korelasi antara karya sastra dan fenomena sosial yang terjadi di sekitar manusia. Berkaitan dengan hal tersebut, Istiqomah, Nuriana, Much. Doyin, (2014) menyatakan bahwa pada hakikatnya karya sastra adalah hasil pengejawantahan kehidupan dari survei yang dilakukan oleh penulis terhadap lingkungan sosial sekitarnya. Realitas kehidupan yang terjadi di sekitar pengarang berupa peran tokoh yang muncul di dunia nyata merupakan bahan mentah dalam penciptaan karya sastra. Bahan mentah tersebut dikreasikan dengan menggunakan daya imajinasi dan kreativitas pengarang dengan menggunakan media bahasa. Media bahasa inilah yang pada akhirnya memunculkan rasa estetika terhadap karya sastra yang dihasilkan oleh pengarang. Lebih lanjut, (Miller, 2011) menyatakan bahwa karya sastra adalah bentuk ungkapan secara khusus yang berupa kata-kata yang merepresentasikan suatu bentuk kebudayaan manusia di suatu masa dan di suatu tempat.

Kaum perempuan harus memperjuangkan dirinya untuk dapat menunjukkan eksistensi di ranah publik. Hal tersebut disebabkan konstruksi budaya yang diciptakan dan dikokohkan oleh kaum patriarki melalui mitos-mitos dan stereotip tentang perempuan menyebabkan perempuan menjadi pihak yang lemah dan tersubordinasi. (Handayani dan Novianto, 2008) menyatakan bahwa mitos-mitos tentang perempuan yang dikonstruksi oleh kaum patriarki mengakibatkan perempuan menjadi sosok yang tersubordinasi dan menjadi the other. Misalnya perempuan dalam konteks budaya Jawa sering disebut sebagai kancawingking ("teman di dapur'). Ada juga mitos tentang swarga nunut neraka katut ('ke surga ikut, ke neraka pun terbawa') yang merepresentasikan bahwa nasib seorang perempuan tergantung oleh laki-laki, dalam hal ini adalah suaminya. Lebih lanjut (Sugihastuti, 2005) menyatakan bahwa perempuan diciptakan oleh Tuhan hanya untuk menyertai laki-laki sehingga eksistensinya sebagai manusia tidak diakui secara wajar. Ketidakwajaran tersebut terlihat dari dikotomi pembagian peran. Dikotomi peran gender menyebabkan persoalan gender. Hal tersebut menyebabkan kesempatan yang diberikan kepada perempuan untuk mengembangkan potensi dan kompetensi diri lebih terbatas jika dibandingkan dengan kesempatan yang diberikan kepada lakilaki. Perempuan menjadi liyan sebab dia tidak pernah menjadi dirinya sendiri. Fakta-fakta tersebut menjadi sumber inspirasi yang tidak akan pernah kering bagi penulis wanita yang ingin menyuarakan dan memperjuangkan 
persamaan hak, baik dua ranah publik maupun di ranah domestik.

Prabasmoro (2007) menyatakan bahwa pemikiran feminis lahir dari konteks sosial kultural yang melingkupi perempuan yang hidup dalam suatu komunitas sosialnya. Melalui gerakan feminisme, perempuan memulai perjuangannya untuk mendapatkan hak yang setara dengan kaum laki-laki. Melalui gerakan tersebut, perempuan meyakini bahwa gender merupakan konstruksi budaya yang menyebabkan perempuan menjadi tertindas dan dirugikan jika dibandingkan dengan kaum laki-laki. Ketertindasan tersebut terjadi karena perempuan meyakini bahwa gender adalah konstruksi budaya produk kaum laki-laki. Perempuan juga memiliki keyakinan bahwa pengetahuan eksperiensial perempuan dapat dijadikan sebagai sebuah dasar pembentukan suatu konstruksi masyarakat nonseksis di masa yang akan datang (Jackson, 2009).

Masalah yang dibahas dalam tulisan ini ialah perjuangan-perjuangan yang dilakukan oleh tokoh perempuan dalam novel Sintren dalam menunjukkan eksistensi dirinya. Dalam hal ini akan dipaparkan strategi yang dilakukan oleh tokoh perempuan dalam perjuangannya tersebut yang terepresentasi dalam novel Sintren karya Dianing Widya Yudistira.

Berdasarkan masalah yang dibahas dalam penelitian ini, tujuan yang hendak dicapai ialah mengungkapkan problematika yang dihadapi oleh kaum perempuan dalam novel Sintren karya Dianing Widya Yudhistira terhadap pembumian mitos tentang perempuan. Selain itu ialah mengungkapkan perjuangan perempuan untuk menunjukkan eksistensialismenya yang terepresentasi dalam novel Sintren karya Dianing Widya Yudistira menjadi tujuan kedua yang akan dicapai dalam tulisan ini.
Beberapa penelitian tentang novel Sintren yang berkaitan dengan persoalan gender pernah dilakukan oleh beberapa peneliti terdahulu. Amrin (2011) dalam tesisnya yang berjudul "Resistensi Perempuan: Kajian Hegemoni Gramsci dalam Novel Sintren Karya Dianing Widya Yudhistira" menyatakan bahwa Konstruksi patriarki dan konsep kapitalis, baik secara sosial ataupun budaya, telah menempatkan perempuan di posisi subordinasi. Kondisi yang subordinat akan dapat berubah ketika perempuan memiliki posisi tawar terhadap dominasi laki-laki sehingga akan muncul proses negosiasi yang menempatkan perempuan pada posisi yang seimbang dengan laki-laki. Halimah (2012) meneliti tentang "Representasi Peran Gender dalam Novel Sintren Karya Dianing Widya" menyatakan bahwa novel Sintren merepresentasikan empat persoalan gender, (1) peran gender yang meliputi peran tradisional dan peran ganda, (2) perbedaan penyifatan gender antara lakilaki dan perempuan, (3) ideologi gender, dan (4) ketidakadilan gender. Makalah Amaliasari (2011) meneliti tentang "Uang dan Ruang Perempuan dalam Novel Sintren" menyatakan bahwa Tokoh Saraswati menemukan uang dan ruangnya Ketika ia menerima pekerjaan sebagai penari sintren. Dengan menari sintren, uang yang didapatkannya dapat digunakan untuk melanjutkan sekolah. Dengan menjadi penari sintren, ruang yang dimilikinya sebagai seorang penari sintren membuat Saraswati memiliki kebebasan dan keleluasaan untuk bereksistensi. Penelitian ini berbeda dengan tiga penelitian yang telah dilakukan meskipun sama-sama membahas persoalan gender yang terepresentasi dalam novel Sintren. Dalam penelitian ini, peneliti tidak hanya mengidentifikasi hambatan perempuan untuk menunjukkan 
eksistensi diri. Peneliti juga mengidentifikasi tindakan tokoh perempuan, dalam hal ini adalah Saras, Menyusun strategi atau langkah untuk dapat menunjukkan eksistensi dirinya. Perjuangan Saras dalam hal pendidikan, pembebasan diri, dan kemampuan menghasilkan modal kapital akan menjadi faktor pendukung perempuan untuk menunjukkan eksisitensi dirinya.

\section{LANDASAN TEORI}

Tong (2009) menyatakan bahwa gelombang gerakan feminis dibagi menjadi tiga gelombang. Gelombang pertama dimulai lebih kurang tahun 1800. Gelombang pertama ini menjadi tonggak gerakkan perempuan berikutnya dalam perjuangan mencari persamaan hak dengan kaum laki-laki. Gelombang kedua muncul sekitar tahun 1960-an yang ditandai dengan perjuangan kaum perempuan dalam pencarian representasi citra perempuan dan kedudukan perempuan. Gelombang ketiga ditandai dengan penyesuaian teori-teori feminis yang muncul dengan pemikiranpemikiran kontemporer. Hal tersebut menyebabkan lahirnya teori-teori feminis yang plural, salah satunya ialah teori feminis eksistensialisme. Tokoh yang memelopori lahirnya teori feminisme eksistensialis adalah Simone de Beauvior. Penggambaran teori tersebut adalah marginalisasi perempuan sebagai liyan dalam kontruksi budaya yang dibentuk oleh kaum laki-laki dan menganggap laki-laki sebagai subyek dan perempuan sebagai obyek. Teori feminis eksistensial merupakan perjuangan perempuan untuk mendapatkan posisi yang setara dengan laki-laki yang dilakukan di ranah domestik dan hal inilah yang membedakan perjuangan aliran feminis lain yang cenderung melakukan perjuangan di ranah publik.
Teori-teori filsafat esistensialisme, khususnya pemikiran-pemikiran Sartre, memiliki peran yang sangat signifikan terhadap pemikiran tokoh tersebut. Salah satu hal yang menarik dari pemikiran Sartre ialah pemikirannya tentang eksistensi manusia. Menurut tokoh tersebut, hal yang membedakan manusia dengan benda-benda yang lainnya ialah manusia ada sebagai dirinya sendiri dengan kesadaran yang ada dalam dirinya. Oleh karena itu manusia menciptakan identitas dan esensi bagi dirinya melalui suatu proses perilaku yang penuh dengan kesadaran dengan cara memilih, memutuskan, dan menegaskan kembali tujuan tindakantindakan yang telah dilakukan, serta menegakkan tujuan dari suatu tindakan yang akan dilakukan dilakukan (Satre dalam Tong, 2006).

Sartre (Susena, 2006) menyatakan bahwa manusia memiliki tanggung jawab terhasdap dirinya sendiri selain tanggung jawab terhadap manusia yang lainnya. Muncul tanggung jawab secara individu dan tanggung jawab secara sosial. Akan tetapi, nilai-nilai yang digunakan sebagai tolok ukur bertanggung jawab tidak pernah ada. Nilai-nilai yang digunakan sebagai tolok ukur adalah sebuah pilihan terhadap apa yang akan kita lakukan. Dengan kata lain eksistensialisme adalah manusia menciptakan dirinya sendiri untuk apa dan menjadi apa. Awalnya manusia memang ada, tetapi manusia belum menjadi apa. Manusia menjadi apa dengan menjatuhkan pilihan yang kemudian diikuti dengan tindakan mengambil keputusan-keputusan atas pilihan yang dipilih. Oleh karena itulah manusia memiliki tanggung jawab terhadap dirinya sendiri atas pilihan dan keputusan yang telah diambilnya.

Simone de Beauvoir (dalam Prameswari, 2019) menyatakan tentang konsep etreensoi ('berada dalam 
dirinya') dan etre pour soi ('berada bagi dirinya'). Entre ensoi merupakan suatu konsep yang menyatakan bahwa ketiadaan kesadaran dalam diri, ketidakmampuan dalam membangun suatu konsep atau tujuan hidup, dan dapat dimetaforkan dengan segala benda yang tidak bernyawa. Etrepour soi merupakan suatu konsep yang berbanding terbalik dengan konsep etreensoi, yaitu hadirnya kesadaran diri, kamampuan untuk merumuskan konsep dan tujuan hidup dalam diri, kemampuan tersebut mengakibatkan tidak dapat diandaikan dengan benda-benda mati. Konsep etre pour soi suatu konsep yang menyatakan bahwa manusia menjadi dirinya sendiri karena dia memiliki kesadaran diri dan tujuan hidup. Mustahil dalam diri manusia memiliki dua konsep tersebut dalam dirinya.

Beauvoir

(Tong,

2006)

menyatakan bahwa ada empat hal yang harus dilakukan oleh perempuan agar perempuan tidak dianggap sebagai the other. Pertama, perempuan harus memiliki pekerjaan atau bekerja. Dengan bekerja di ranah publik, perempuan akan memiliki peluang atau kesempatan untuk mendapatkan kembali transendensinya. Dengan bekerja perempuan tidak akan lagi menjadi objek dalam menentukan apa yang ingin dilakukannya. Dengan bekerja, perempuan akan memiliki kekuatan untuk menjadi dirinya sendiri secara utuh. Kedua, perempuan harus menjelma menjadi sosok yang intelek. Dengan menjadi sosok yang intelek, perempuan akan menjadi subyek pemikir terhadap hal-hal yang akan mengubah perempuan. Perempuan tidak lagi menjadi objek pemikiran. Ketiga, Perempuan harus memiliki kekuatan ekonomi. Dengan memiliki kekuatan ekonomi, perempuan akan mampu mencapai transformasi sosialis masyarakat. Kekuatan ekonomi dapat digunakan untuk menyediakan dukungan material dalam mentransendensikan dirinya. Keempat, perempuan harus membebaskan dirinya terhadap mitosmitos tentang perempuan. Misalnya perempuan harus dapat mendekonstruksi mitos tentang kaumnya yang dianggap melakukan hal-hal yang tidak efektif dan efisien dalam penggunaan waktu. Mitos tentang perempuan di salon harus dapat didekonstruksi dengan perempuan yang melakukan kegiatan untuk pelayanan terhadap orang lain.

\section{METODE PENELITIAN}

Metode yang digunakan dalam penelitian ini adalah metode deskriptif. Melalui penelitian ini, peneliti mendeskripsikan perjuangan perempuan untuk menunjukkan eksistensialismenya yang terepresentasi dalam novel Sintren karya Dianing Widya Yudistira. Pendeskripsian temuan didasarkan pada hasil analisis terhadap data

Data primer dalam tulisan ini adalah novel yang berjudul Sintren karya Dianing Widya Yudistira. Teori feminis eksistensialisme menjadi dasar dalam melakukan analisis terhadap data. Hasil analisis data dinarasikan sehingga akan menghasilkan suatu informasi tentang hambatan dan perjuangan perempuan yang terepresentasi dalam novel Sintren karya Dianing Widya Yudistira.

Langkah penelitian yang ditempuh terdiri atas beberapa tahap. Pertama pengumpulan data. Dua jenis data yang dikumpulkan adalah data primer berupa novel Sintren dan data sekunder berupa tulisan-tulisan dalam bentuk artikel, jurnal, laporan penelitian yang ada kaitannya dengan permasalahan yang dibahas dalam tulisan ini. Data sekunder dikumpulkan dengan cara menginventarisasi tulisan-tulisan dari berbagai sumber. Kedua, peneliti melakukan analisis data. Metode kualitatif diterapkan untuk menganalisis 
data. Teori feminisime eksistensialisme digunakan untuk menjawab problematika yang dihadapi oleh perempuan ketika ingin menunjukkan eksistensinya dan menjawab persoalan perjuangan yang dilakukan oleh perempuan untuk menunjukkan eksistensinya.

\section{PEMBAHASAN}

Banyak hambatan yang harus dihadapi oleh perempuan dalam perjuangannya untuk menyamakan eksistensinya dan menyamakan hak dengan laki-laki, baik di ranah domestik maupun ranah publik. Hambatan tersebut berasal dari luar maupun dari dalam diri perempuan sendiri.

Salah satu hambatan tersebut adalah tradisi atau adat-istiadat yang berlaku dalam kehidupan komunitas sosial. Tradisi atau adat-istiadat akan sangat menarik jika pembicaraan dikaitkan dengan kaum perempuan dan gerakan feminisme. Kaum perempuan yang terepresi oleh adat-istiadat kontruksi kaum laki-laki membuat perempuan tidak pernah menjadi dirinya sendiri. Perempuan menjadi the second class dan tidak memiliki kebebasan untuk beraktivitas di ranah publik. Tradisi menjadi semacam media atau alat yang digunakan oleh kaum patriarki untuk membumikan dan mengukuhkan konstruksi budaya yang dibentuknya. (Sugihastuti dan Adif Sofia, 2003) menyatakan bahwa tradisi yang dibuat oleh kaum patriarki memiliki peran yang sangat signifikan terhadap lambannya perkembangan gerakan feminisme. Hal tersebut disebabkan hegemoni adat konstruksi kaum patriarki masih sangat kuat bercokol dan belum munculnya nilai-nilai baru yang sekiranya memiliki kekuatan untuk menggeser kosntruksi budaya tersebut. Dalam novel Sintren, tradisi yang berhasil diidentifikasi menghambat kaum perempuan untuk bereksistensi diri terepresentasi dari sikap Emak Saraswati yang masih berpegang teguh pada konstruksi budaya patriarki. Hal tersebut dapat dilihat dalam kutipan berikut ini.

"Ganti baju!" kata Mak garang.

Kalimat pendek itu terasa petir menghujam ke jantung Saraswati. Saraswati hanya bisa tertunduk sembari membetulkan tali sepatunya yang sudah uzur. (Yudhistira, 2007).

"Saya ingin masuk sekolah, Mak."

"Tidak tahu malu! Uang sekolahmu nunggak sampai tiga bulan, kamu masih mau masuk. Mau ditaruh di mana mukamu itu?"

"Ayo tunggu apalagi. Ganti bajumu. Ikut Mak ke Klidang. Pagi ini Mak harus menjemur ikan. Mak tidak sanggup kerja sendiri. Kamukan tahu bapakmu lagi sakit." (Yudhistira, 2007).

"Alaah, seperti anak orang kaya saja mau sekolah terus. Sudah bisa baca sama nulis, untuk anak perempuan itu sudah cukup." (Yudhistira, 2007).

$\begin{array}{rrr}\text { Kutipan } & \begin{array}{r}\text { tersebut } \\ \text { konstruksi }\end{array} & \begin{array}{r}\text { sangat } \\ \text { budaya }\end{array}\end{array}$ patriarki. Larangan terhadap anak perempuan untuk mengenyam pendidikan lebih tinggi merupakan aksi penghambatan dan pembatasan untuk memiliki pemikiran yang lebih maju, mengembangkan pola pikir, dan menyetarakan hak perempuan dengan laki-laki dalam hal pemerolehan Pendidikan. Pembatasan terhadap kesempatan untuk mendapatkan Pendidikan yang lebih tinggi membuat perempuan menjadi bodoh, pola pikirnya tidak berkembang, dan menjadi sosok yang tidak memiliki kesempatan yang luas untuk beraktivitas di ranah publik melalui dunia kerja. Hal tersebut yang membuat perempuan bergantung kepada 
laki-laki. Perempuan menduduki posisi yang diberi, dilindungi oleh laki-laki sehingga konstruksi budaya patriarki akan semakin kokoh dan kuat.

Susunan dan sistem masyarakat Indonesia memiliki kecenderungan berbentuk patriarki. Perempuan menjadi pihak yang sangat dirugikan degan bentuk sistem kemasyarakatan tersebut,baik dari segi hukum ataupun aspek kehidupan yang lainnya (Faiqoh, 2001). Hal tersebut merepresentasikan bahwa laki-laki memiliki kekuasaan dari konstruksi budaya yang dibentuknya. Melalui konstruksi tersebut laki-laki membuat posisi perempuan menjadi lebih rendah jika dibandingkan dengan posisi kaum laki-laki. Konstruksi tersebut dikonstitusionalisasikan melalui ritual, tradisi, adat-istiadat, bahkan melalui hukum.

Sehubungan dengan sistem sosial tersebut, diyakini (dijadikan ideologi) bahwa pria lebih superior dibanding perempuan sehingga perempuan sudah seharusnya dikendalikan (dikontrol) oleh pria dan menjadi bagian dari properti pria. Adanya model patriarki ini menimbulkan ketidaksetaraan relasi gender, sosial, ekonomi, dan politik. Dalam novel Sintren hal tersebut terepresentasi dalam kutipan berikut ini.

"Saraswati itu perempuan, Pak. Apa perlu perempuan sekolah sampai tinggi-tinggi? Buat Mak , yang penting bisa baca sama ngitung, itu sudah cukup. Toh, nantinya kalau dia kawin ya kerjanya di dapur." (Yudhistira, 2007).

Kutipan tersebut merepresentasikan begitu kuatnya konstruksi budaya yang telah dibentuk oleh kaum laki-laki. Dalam konstruksi tersebut perempuan dibentuk oleh laki-laki. Perempuan tidak memiliki kebebasan dalam beraktivitas karena kaum perempuan terikat dengan aturan dan norma-norma yang dikonstruksi oleh kaum laki-laki. Perempuan terdomestifikasi oleh tradisi sehingga tidak memiliki kesempatan untuk menunjukkan esensi serta potensi yang ada dalam dirinya. Oleh karena itu tidak ada manfaatnya perempuan sekolah karena ujung-ujungnya akan kembali ke urusan dapur, kasur, dan sumur. Dengan tradisi tersebut, perempuan menjadi terobjektifikasi dan mengabaikan bahkan meniadakan peran subjeknya.

\section{Perjuangan Perempuan untuk Menyamakan Eksistensi dengan Laki-laki}

Ketika perempuan ingin menyamakan eksistensinya agar diakui seperti laki-laki oleh lingkungan sosialnya, perempuan harus berani melakukan gerakan-gerakan yang mengarah kepada perlawanan terhadap tatanan konstruksi budaya yang dibentuk oleh laki-laki. Seperti yang diungkapkan oleh Thornham (2010) yang menyatakan bahwa ketika perempuan mulai dapat eksis untuk diri sendiri, maka ia akan dapat menciptakan kemerdekaan untuk dirinya sendiri. Dengan demikian, masa depan yang lebih baik akan terbuka lebar untuk perempuan karena ia telah memiliki kebebasan untuk beraktivitas di ranah publik seperti halnya laki-laki. Perempuan menjadi sosok perempuan yang utuh, tidak menjadi pihak yang tersubordinasi dan tidak lagi menjadi liyan.

Dalam novel Sintren beberapa upaya dilakukan oleh tokoh perempuan untuk dapat menunjukkan eksistensinya agar keberdaannya dan kendudukanya mendapatkan pengakuan dari laki-laki sehingga perempuan tidak lagi menjadi liyan. Perjuangan yang dilakukan oleh tokoh perempuan untuk mencapai hal tersebut adalah sebagai berikut.. 


\section{Berjuang di Bidang Pendidikan untuk Menjadi Sosok yang Cerdas.}

Konstruksi budaya patriarki menyebabkan dikotomi peran di ranah publik antara laki-laki dan perempuan. Peran sosial inilah yang pada akhirnya memunculkan aturan sosial tentang suatu hal yang boleh dilakukan oleh laki-laki dan tidak boleh dilakukan oleh perempuan, atau sebaliknya, tidak boleh dilakukan laki-laki tapi boleh dilakukan perempuan. Terkait dengan persoalan tersebut, (Edriana Noerdin, 2006) menyatakan bahwa konsep gender yang berorientasi pada tingkah laku dan atribut yang dilekatkan pada laki-laki dan perempuan yang dikonstruksi oleh budaya akan mengakibatkan munculnya suatu dikotomi tentang pantas atau tidak pantas atas perbuatan yang dilakukan oleh laki-laki ataupun perempuan. Jika laki-laki tidak mengenyam pendidikan sehingga tidak mampu menafkahi keluarganya, perbuatan laki-laki tersebut dianggap tidak pantas. Begitu juga sebaliknya, perempuan yang mengenyam pendidikan tinggi sehingga dia memiliki aktivitas di ranah publik seperti laki-laki, maka perbuatan tersebut juga dianggap tidak pantas. Tugas laki-laki adalah memberi dan tugas perempuan adalah menerima. Pembagian peran tersebut akan melahirkan konsep memberi dan diberi. Pihak yang memberi akan memiliki posisi yang lebih tinggi jika dibandingkan dengan pihak yang diberi. Sistem budaya yang paternalistik memiliki peran yang sangat signifikan terhadap kondisi tersebut.

Dalam hal ini laki-laki memiliki posisi yang lebih tinggi daripada perempuan. Untuk dapat mendekonstruksi konstruksi budaya tersebut, sosok perempuan harus menjelma menjadi sosok yang memiliki intelektualitas tinggi. Dengan intelektualitas yang tinggi perempuan akan mampu menjadi atau memiliki posisi sebagai sosok pengambil keputusan untuk memperjuangkan halhal yang berhubungan dengan kepentingan kaum perempuan. Oleh karena itu sudah sewajarnya jika perempuan dan laki-laki mendapatkan kesempatan yang sama untuk mengenyam pendidikan di bangku sekolah. Akan tetapi, hambatan kultural selalu muncul sebagai akibat dari konstruksi budaya patriarki. Anggapan yang muncul di dalam pemikiran masyarakat ialah percuma perempuan sekolah tinggi-tinggi karena dia tidak akan bekerja.

Saraswati memiliki keinginan untuk melanjutkan sekolah dan berjuang untuk mewujudkan keinginannya tersebut degan menjadi sintren. Bayaran yang ia terima dengan menjadi sintren dipergunakan untuk memenuhi kebutuhan-kebutuhan yang diperlukan di sekolah. Keinginan keras tokoh Saraswati untuk mendapatkan pendidikan yang layak terepresentasi dalam kutipan berikut.

"Kalau memang Saras ingin melanjutkan ke SMP ia harus mau jadi sintren."

Saraswati terkejut., Mak menyebutnyebut sekolah.

"Jumlahnya bisa untuk membayar uang gedung, spp, dan seragam sekolah SM P, Pak."

"Saras mau." Saras tiba-tiba menimpali pertengkaran Mak dan Bapaknya.

Kedua orang tua itu pun menoleh ke arah Saraswati. "Tapi kalau betulbetul Saras bisa sekolah SMP, Saras mau jadi sintren." (Yudhistira, 2007).

Kutipan tersebut merepresentasikan perjuangan tokoh perempuan, Saras, untuk dapat melanjutkan sekolah meskipun dia harus menjadi sintren. 
Salah satu media yang dapat meningkatkan intelektual perempuan adalah sekolah sehingga perempuan tidak hanya memiliki tanggung jawab terhadap pekerjaan rumah tangga, melainkan juga memiliki tanggung jawab terhadap masyarakat yang ada di sekitarnya melalui pekerjaan yang dilakukannya. Saras menyadari bahwa kemiskinan yang membelit keluarganya tidak memungkinkan mewujudkan keinginannya untuk mendapatkan pendidikan yang tinggi. Hal yang dapat dilakukan untuk mewujudkan impiannya adalah dengan bekerja mencari uang.

Profesi sintren sangat menjanjikan karena dapat mengahasilkan modal kapital yang sangat besar. Dengan memiliki modal kapital yang besar, Saras dapat melanjutkan ke jenjang sekolah yang lebih tinggi lagi. Bagi Saras, pendidikan adalah pintu gerbang untuk dapat mewujudkan impiannya. Hal tersebut menyulut semangat Saras untuk menerima pekerjaan sebagai sintren.

\section{Pembebasan Diri}

Keadaan yang membelenggu perempuan menempatkan perempuan harus mengambil suatu keputusan untuk dirinya sendiri. Hanya ada dua pilihan. Pertama, bertahan dan terkungkung oleh keadaan. Kedua, perempuan melakukan tindakan perlawanan terhadap keadaan sehingga ia dapat membebaskan diri dari kondisi atau keadaan yang mengungkungnya. Ketika keputusan sudah diambil maka perempuan harus mempertanggungjawabkan keputusan yang telah diambilnya, baik tanggung jawab terhadap dirinya sendiri ataupun tanggung jawab terhadap lingkungan sosial yang ada di sekitarnya.

Dihadapkan pada kungkungan keadaan ekonomi yang menghambat keinginannya untuk sekolah, Saraswati mengambil keputusan untuk keluar dari belenggu tersebut.

Faktor ekonomi menjadi salah satu penyebab perempuan tidak memiliki kesempatan yang luas utuk menunjukkan dan mengembangkan eksistensi yang ada dalam dirinya. Dikotomi kekuatan ekonomi dalam ranah kaya dan miskin memunculkan kelas sosial yang mendominasi dan didominasi. Pihak yang memiliki kekuatan ekonomi dan masuk dalam ranah kaya akan menjadi pihak yang mendominasi. Pihak yang tidak memiliki kekuatan ekonomi dan masuk dalam kelas eknomi miskin akan menjadi pihak yang didominasi. Tokoh Saraswati berasal dari keluarga yang masuk di ranah miskin. Oleh arena itu keluarga Saraswati tidak memiliki kekuatan untuk menolak keinginan juragan Wargo menikahkan Saraswati dengan anak laki-lakinya. Perlawanan muncul dari diri Saraswati untuk menolak keinginan orang tuanya. Untuk membebaskan dirinya dari kungkungan kemiskinan, Saraswati mau menjadi sintren meskipun ia tidak begitu mengenal dan memahami sintren. Pilihan menjadi sintren tetap dipilih meskipun ia tahu konsekuensi pilihannya itu berat. Dia harus dapat membagi waktu antara main sintren dan belajar. Hal tersebut terepresentasi dalam kutipan berikut.

Matahari telah lingsir. Hari mulai gelap. Saraswati menutup buku tugasnya. Seusai tidur siang tadi, ia langsung mengerjakan tugas sekolah sekaligus belajar untuk pelajaran besok pagi. Nanti malam ia harus menari sintren lagi.

Saraswati masih belum bisa percaya kalau sekarang ia seorang penari sintren. Dulu ia pernah melihat sintren tapi hanya sebentar, jadi sebenarnya ia tak begitu mengenal tentang sintren. Kalau bukan untuk biaya sekolah, ia tak akan mau 
menerima pekerjaan ini. Kalau saja ia anak orang mampu, ia tak akan pernah jadi sintren. Tetapi kenyataan mengharuskan seseorang melakukan sesuatu atau menjadi sesuatu tanpa bisa menawar (Yudhistira, 2007).

Tokoh Saras juga membebaskan dirinya dari rasa kecewa terhadap keputusan Juragan Wargo untuk membatalkan niat melamar dirinya. Meskipun pada awalnya rasa kesal dan kecewa itu muncul, Saraswati mengambil sebuah tindakan untuk tidak lagi memikirkan itu dan keluar dari persoalan tersebut. Keadaan ekonomi keluarganya yang masuk ke dalam ranah miskin tidak berani melakukan perlawanan terhadap keputusan keluarga Juragan Wargo yang sangat kaya. Untuk itulah Saraswati harus melupakan Kirman dan menghilangkannya dalam kehidupannya. Sikap tanggung jawab Saraswati atas keputusannya itu terepresentasi dalam kutipan berikut.

"Maaf siapa ya?" Saraswati seolah lupa dengan teman sekelasnya yang selama ini suka usil.

Wati menautkan kening.

"Anak baru, ya?"

"Baru jadi sintren saja sudah sombong."

"Saya benar-benar baru melihat kamu."

Wati menghela nafas jengkel. "Sombong banget! Asal kamu tahu ya, kemarin sore Kirman datang melamarku."

Sekarang giliran Saraswati menautkan kening kuat-kuat.

"Kirman?"

"Ya Kirman. la me-la-mar-ku," ucap Wati sepatah-patah.

"Apa hubungannya denganku?" (Yudhistira, 2007).

Kutipan tersebut merepresentasikan konsekuensi dari keputusan yang diambil Saraswati. Rasa tidak peduli terhadap Kirman membuat rasa kehilangan dalam diri Saraswati tidak ada lagi. Saraswati menjauhkan diri dari kondisi yang sangat mengecewakannya dengan cara menukar bentuk-bentuk kebahagiaan yang akan ia dapatkan ketika menjadi istri Kirman dengan sesuatu yang jauh lebih berharga untuk ia raih sebagai bekal di masa yang akan datang, yaitu melanjutkan sekolah dan mengumpulkan modal kapital yang akan mengeluarkan keluarganya dari kungkungan kemiskinan.

Saraswati juga berusaha untuk membebaskan diri dari kungkungan tradisi yang berupa kawin muda. Adatistiadat yang berlaku di komunitas sosial memaknai perkawinan sebagai sesuatu kewajiban sosial yang harus dilakukan oleh anggota masyarakat karena sudah dianggap sebagai sebuah warisan tradisional peninggalan konstruksi budaya yang telah ada. Dalam hal ini seseorang tidak mampu untuk menolak karena perkawinan bukan dianggap sebagai sebuah pilihan, melainkan dianggap sebagai sebuah keharusan yang harus dilaksanakan. Oleh karena cara pandang seperti itu, kawin paksa masih tetap akan terjadi karena perkawinan dianggap sebagai sebuah kewajiban sosial.

Kenyataannya ia perempuan. Harus menuruti kehendak orangtua. Sekolah sangat dibatasi. Yang mengenaskan, orang-orang di kampugnya akan merasa senang bila Anak gadisnya cepat dilamar orang, yang berarti anaknya cepat laku. Banyak teman perempuan Saraswati sudah akan dinikahkan begitu selesai sekolah dasar nanti (Yudhistra, 2007).

Kamu harus kawin dengan Kirman, Saras. Harus. Mak akan berusaha sekuat mungkin untuk itu, Batinnya (Yudhistira, 2007). 
Kawin paksa merupakan salah satu hambatan yang menyebabkan perempuan akan tetap menempati posisinya sebagai the second class. Perempuan tidak diberi kebebasan untuk menetukan pilihannya. Perempuan sebagai subyek terabaikan dan diposisikan oleh tradisi dan adat-istiadat konstruksi patriarki sebagai obyek. Kebudayaan dominan yang dikonstruksi oleh kaum patriarki salah satunya terepresentasi dalam tindakan kawin paksa.

Saraswati menolak keinginan emaknya untuk dinikahkan dengan anak juragan Wargo sebagai suatu bentuk perlawanan untuk membebaskan diri dari adat kawin muda. Kawin muda akan merampas kesempatan perempuan untuk menunjukkan eksistensi dirinya di ranah sosial. Hal tersebut disebabkan oleh suatu norma yang menunjukkan bahwa perkawinan menjadi salah satu media sebagai legalitas seorang laki-laki untuk memiliki tubuh dan seksualitas kaum perempuan. Ketika tubuh dan seksualitas perempuan telah menjadi milik laki-laki, maka perempuan tidak akan pernah memiliki tubuhnya secara penuh. Perempuan akan menjadi liyan. Hal tersebut disebabkan laki-laki memiliki kekuasaan untuk mengontrol tubuh dan seksualitas perempuan sesuai dengan konstruksi yang telah dibuat dan dikonstitusikan. Muncul kebudayaan dominan yang membuat perempuan menjadi pihak didominasi dan laki-laki menjadi pihak mendominasi. Penolakan Saraswati terepresentasi dalam kutipan berikut.

Mak tertawa mendengar penjelasan Saraswati. "Itu karena juragan Wargo ingin kamu jadi menantunya."

"Mak, Saras masih ingin sekolah. Saras tidak mau buru-buru kawin."

"Kawinnya tidak sekarang, bisa nunggu tahun depan."
"Tidak mau..." sambil berlari masuk kamarnya, menahan kejengkelannya. (Yudhistira, 2007)

"Saraswati tak peduli, pokoknya Saras belum mau kawin. Saras masih ingin sekolah...."Tidak, Saras ingin sekolah sampai sarjana." (Yudhistira, 2007).

Kawin muda setelah lulus sekolah dasar. Sangat mengerikan bagi Saraswati. Ia ingin skolah hingga SMP, SMU, kalau bisa sampai kuliah (Yudhistira, 2007).

"Aku akan punya anak, akan tua. Lalu kapan aku menikmati masa remaja. Tidak. Aku tidak mau kawin dulu." (Yudhistira, 2007).

Salah satu bentuk resistensi yang dilakukan oleh Saraswati untuk membebaskan diri dari tradisi adalah menolak keinginan emaknya untuk membantu bekerja di klidang milik juragan Wargo. Penolakan. Hal tersebut terepresentasi dalam kutipan berikut ini.

"Mak langsung berteriak memanggil Saraswati begitu sampai di ambang pintu. Mak tak peduli waktu Maghrib telah turun. Tidak sopan kata orangorang tua, berteriak-teriak di waktu maghrib."

"Masuk dulu, bicara yang baik Mak."

"Bapak kan sudah kuingatkan kasih tau dia supaya bantu aku."

"Dia segan."

"Dasar pemalas!"

"Bukannya dia malas tapi takut.

Mak mengerutkan dahinya.

"Di sekolahnya, katanya kabar diam kau dikawinkan sama anak juragan Wargo tersebar santer. Dia malu dan tak berani ke Klidang." (Yudhistira, 2007) 


\section{Menghasilkan Modal Kapital}

Mitos perempuan yang hanya menjadi pihak menerima uang dari lakilaki sebagai pencari nafkah mengakibatkan perempuan tidak memiliki kekuatan untuk menyetarakan diri dengan laki-laki dan membuat perempuan memiliki ketergantungan yang akut terhadap keberadaan laki-laki untuk memenuhi kebutuhannya. Hal inilah yang mengakibatkan perempuan selalu menjadi the other. Agar dapat keluar dari situasi dan mitos yang dibumikan oleh kaum patriarki, perempuan harus mampu menghasilkan modal kapital. Modal kapital akan dapat diperoleh perempuan dengan cara melibatkan diri di urusan publik melalui pekerjaan produktif yang menghasilkan modal kapital. Hal tersebut terepresentasi dari tokoh-tokoh perempuan yang muncul di novel Sintren.

Tokoh Mak dalam novel tersebut direpresentasikan sebagai sosok yang terlibat dalam pekerjaan produktif dan mengantikan peran laki-laki (Bapak) di ranah publik ketika tokoh laki-laki sakit dan tidak berdaya untuk terlibat dalam pekerjaan produktif.

Sampai di rumah, Surti nyerocos di depan suaminya kalau juragannya memberinya uang sangat banyak.

"Mana ada juragan sebaik dia, Pak."

Bapak mengiyakan dengan anggukan kepala.

"Tapi apa maksudnya ya, Pak."

"Orang baik tak punya maksud

tertentu kalau member sesuatu ke orang lain."

"K ok sebanyak ini."

"Ya wajar. Wong kamu sudah bertahun-tahun megabdi sama juragan Wargo. Ya di Klidang, juga di sawah." (Yudhistira, 2007).
Keterlibatan perempuan di ranah publik untuk dapat mengahasilkan modal kapital menunjukkan bahwa perempuan sebenarnya memiliki potensi yang sama dengan laki-laki jika kesempatan dan peluang diberikan kepada perempuan. Tokoh Emak membantu Bapak dalam memikul beban tanggung jawab untuk pemenuhan kebutuhan ekonomi menunjukkan hal tersebut. Eksistensi dan kompetensi perempuan menjadi terakui ketika laki-laki tidak lagi mampu menghasilkan modal kapital untuk memenuhi kebutuhan keluarganya. Hal tersebut terepresentasi dalam kutipan berikut ini.

Terdengar helaan nafas Marto yang berat. Ia menyesali kenyataan. Kalau saja ia mampu menafkahi istri anak satu-satunya, pasti istrinya tak perlu uring-uringan sepagi ini."

...

Tak punya pekerjaan tetap, itulah yang membuat Marto dan keluarganya terjerat dalam kemiskinan. Ibarat orang tercebur ke sungai, Marto tak bisa berenang. Ia hanya bisa mengikuti ke mana air menghanyutkan dirinya.." (Yudhistira, 2007).

Kutipan tersebut merepresentasikan keputusasaan lakilaki dalam menghasilkan modal kapital. Keterbatasan yang dimilikinya akhirnya membuat laki-laki memberikan kesempatan kepada perempuan untuk beraktivitas di ranah sosial dan mengakui komptensi perempuan dalam menghasilkan modal kapital. Bahkan ia dengan berat hati mengizinkan putrinya untuk menjadi sintren agar dapat melanjutkan sekolah ke jenjang yang lebih tinggi.

"Semestinya kita tak boleh megeluh di depan Saras, apalagi memojokkan dia. Mak selalu mengatakan seorang 
perempuan cukup bisa membaca dan, toh nantinya akan hanya di dapur saja."

Mak terdiam.

"Kalau begitu terus pikiran kita, kapan kita lepas dari kemiskinan ini. Apa kamu berniat mewariskan kemiskinan ini kepada Saras."

Mak kali ini menghembuskan nafas.

"Terus sekarang bagaimana Pak?"

"Bagaimana apa maksudmu?"

"Nanti malamSaras mulai jadi

sintren."

"Ya jalani saja. Mau bagaimana

lagi. Toh, uangnya nanti untuk sekolah ke SMP."." (Yudhistira, 2007).

Selain Mak, tokoh perempuan lain yang memiliki kegiatan di ranah publik adalah Saraswati. Saraswati merepresentasikan perempuan perkerja yang berorientasi pada pemenuhan kebutuhan hidup di bidang pendidikan. Pilihannya bekerja menjadi sintren sekaligus harus bertanggung jawab terhadap kewajiban di sekolah membuktikan bahwa perempuan memiliki kemampuan untuk mengaktualisasi eksistesialismenya meskipun ia memiliki dua tanggung jawab yang harus berhasil semua. Dalam hal ini, perempuan tidak lagi menjadi objek, melainkan menjadi subjek, menjadi sosok perempuan yang memiliki kesempatan untuk menentukan apa yang dianggap baik untuk dirinya. Bekerja di ranah publik akan membentuk perempuan menjadi dirinya sendiri.

Dengan kemampuan untuk produktif di modal kapital, perempuan tidak akan mengantungakan diri sepenuhnya kepada laki-laki di bidang kapital. Selain itu, perempuan akan mendapatkan kesempatan yang sama untuk berkiprah di ranah publik sama halnya dengan laki-laki. Pergaulan perempuan juga menjadi tambah luas,

dengan demikian pengetahuan perempuan juga akan mengalami perubahan yang signifikan. Kemampuan perempuan dalam menunjukkan eksisitensinya untuk berkiprah di ranah sosial dan menghasilkan modal kapital terepresentasi melalui tokoh Saras dalam kutipan berikut ini.

Begitu sampai di rumah, Saraswati membuka lembaran uang yang ia gulung-gulung dan hanya digenggamnya saja. Mak terkesima. Baru kali ini ia melihat uang begitu banyak. Saraswati menghitung uang itu. Lumayan, ada dua puluh lima ribu. Saraswati membagi dua uang itu.

"Ini buat Mak lima belas ribu," sambal mengulurkan lembaranlembaran uang itu dengan tangan kanannya. Tangan kirinya memegang lembaran-lembaran lainnya. "Yang ini mau Saraswat tabung." ." (Yudhistira, 2007).

Kutipan merepresentasikan perempuan dalam mengaktualkan eksistensi di ranah publik. Saras dapat membantu meringankan beban ekonomi keluarganya ketika ia diberi izin dan kesempatan untuk menjadi seorang penari sintren. Profesi yang digeluti Saras menghasilkan modal kapital yang mampu menopang kebutuhan ekonomi keluarga dan membiayai sekolahnya.

\section{PENUTUP}

Banyak halangan dan rintangan yang harus dihadapi oleh tokoh Saras ketika mereka ingin mengaktualkan diri. Halangan muncul dari faktor eksternal dan internal. Faktor eksternal berupa tradisi yang dianut dan berlaku di komunitas sosial, yaitu budaya patriarki. Konstruksi budaya patriarki mengakibatkan perempuan tidak 
memiliki kebebasan untuk menunjukkan eksistensi diri. Kehidupan sosial yang masih sangat memegang tradisi patriarki, pernikahan dini, dan kawin paksa yang muncul dalam novel Sintren merepresentasikan begitu kuatnya membelenggu perempuan. Perempuan kehilangan kesempatan untuk menunjukkan eksistensinya di ranah publik. Perempuan akan selalu menjadi the other. Muncul penyebab lain yang membuat tokoh perempuan dalam novel Sintren kesulitan untuk menunjukkan eksistensi dirinya, yaitu sifat ambivalen perempuan itu sendiri.

Perjuangan yang dilakukan oleh tokoh perempuan dalam novel Sintren untuk dapat diakui eksistensi dirinya melalui tiga hal. Ketiga hal tersebut adalah perjuangan untuk mendapatkan kesempatan meraih Pendidikan yang tinggi, membebaskan diri dari segala hal yang menghambat perjuangannya, dan menghasilkan modal kapital dengan cara bekerja. Perempuan harus berjuang untuk mendapatkan peran sosial yang diinginkan, sedangkan laki-laki tanpa perjuangan peran sosial sudah melekat dalam dirinya. Sebuah ketimpangan gender memunculkan persoalan gender.

\section{DAFTAR PUSTAKA}

Amaliasari, D. (2011) Uang dan ruang perempuan dalam novel Sintren. Diperoleh dari http://pustaka.unpad.ac.id/wpcontent/uploads/2011/03/uang_da n_ruang_perempuan_dlm_novel_ sintren.pdf

Faiqoh. (2001) Wanita dalam masyarakat Indonesia: Akses pemberdayaan dan kesempatan. Yogyakarta: Sunan Kalijaga Press.

Edriana Noerdin (2006) Strategi mengentaskan kemiskinan berbasis gender: Potret kemiskinan perempuan. Jakarta: Women Reasearch Institute.

Halimah. (2012) Representasi peran gender dalam novel Sintren karya Dianing Widya.

Handayani, C. S. dan N. A. (2008) Kuasa wanita Jawa. Yogyakarta: LkiS.

Istiqomah, Nuriana, Much. Doyin, dan S. (2014) 'Sikap hidup orang Jawa dalam novel Orang-Orang Proyek karya Ahmad Tohari', Jurnal Sastra Indonesia, 3/1, pp. $1--9$.

Jackson, S. dan J. J. (2009) Teori-teori feminisme kontemporer. Yogyakarta: Jalasutra.

Miller, H. J. (2011) Aspek Kajian sastra. Yogyakarta: Jalasutra.

Prabasmoro, A. P. (2007) Kajian budaya feminis tubuh, sastra, dan budaya Pop. Edited by Jalasutra. Yogyakarta.

Prameswari, dkk. (2019) 'Feminisme eksistensial Simone De Beauvoir: perjuangan perempuan di ranah domestik', OJS Unud, 1(2), pp. $1-13$.

Sofia, S. A. (2003) Feminis dan sastra. Bandung: Katarsis.

Suharto, S. (2005) Kritk sastra feminis: Teori dan aplikasinya. Yogyakarta: Pustaka Pelajar Offset.

Susena, F. M. (2006) Etika abad ke-20. Yogyakarta: Kanisius.

Thornham, S. (2010) Teori feminis dan culture studies. Yogyakarta: Jalasutra.

Tong, R. P. (2006) Feminist thought. Pengantar paling komprehensif kepada arus utama pemikiran feminis. Yogyakarta: Jalasutra.

Yudhistira, D. W. (2007) Sintren. Jakarta: PT Gramedia Widisarana Indonesia. 